\title{
The Fish Health Program and the Occurrence of Fish Diseases in the Pacific Region of Canada
}

\author{
Gordon R. BeLl and Leo MARgolis \\ Department of the Environment, Fisheries and Marine Service, \\ Pacific Biological Station, Nanaimo, B.C. V9R 5K6, Canada
}

\begin{abstract}
The organization and operation of the fish health program in the Pacific Region (British Columbia and the Yukon Territory) of Canada are described and placed within the context of the Federal Fisheries Act that basically governs all fisheries activities in Canada. This program has three components: health certification, diagnostics-consultation, and research, each of which is briefly described.

Frequently occurring or threatening diseases or disease agents in the Pacific Region are listed and some comments are made on the more important ones.
\end{abstract}

\section{Introduction}

Artificial and intensive means of salmonid production, such as hatcheries, spawning channels and fishfarms, are becoming increasingly important in contributing to the overall production of Canada's Pacific salmonid resources. (MacCrimmon et al. (1974) have reviewed the status of certain fish culture activities in Canada). The success of these operations is considerably dependent upon the ability to prevent or control disease outbreaks. Salmonid stocks must also be protected from infection by exotic diseases that may be introduced through man's manipulation of the resource or the environment. There is, then, a continuing and increasing need for a fish health program.

This paper will discuss the organization and operation of the recently implemented fish health program in the Pacific Region of Canada and review the status of fish diseases, particularly in this Region. (For fisheries administrative purposes the Pacific Region includes the Province of British Columbia, the Yukon Territory and their offshore waters.) Emphasis will be placed upon diseases of salmonids, the economically most important fisheries resource of this area.

\section{Fish Health Regulations}

It is necessary first of all to place the Pacific Region fish health program within the framework of national and provincial fish health regulations. A much more extensive discussion is given in a document prepared by the now disbanded Canadian Committee on Fish Diseases (1972).

\section{National}

Under the Fisheries Act of 1932, the Federal (national) government has the power to make regulations concerning all aspects of the management of fisheries resources in each of the 10 provinces, and has the responsibility of administering and enforcing these regulations. However, by mutual agreement most provinces manage their own freshwater fisheries resources. Marine and anadromous salmon resources of coastal provinces are for the most part managed by the Federal Government. For example, salmon and shellfish resources in British Columbia are a federal responsibility whereas the trouts and chars, including steelhead, are managed by a provincial agency.

The federally operated Fisheries and Marine Service is part of the Department of the Environment with headquarters in Ottawa, 
but with regional offices across the country. Among its responsibilities this Service is involved in management, research and development of the fisheries resources. The laboratories and stations formerly operated by the Fisheries Research Board of Canada are now an integral part of the Fisheries and Marine Service.

The Salmonidae Import Regulations of 1969 (amended in 1971), promulgated under the Federal Fisheries Act, forbid the importation of live or dead salmonids or their eggs unless they have been processed in such a way as to kill the spores of Myxosoma cerebralis (causative agent of "whirling disease") and the virus causing viral haemorrhagic septicaemia (V. H. S., "Egtved" disease), or the shipment has been inspected and certified by a federally recognized fish pathobiologist as being free of the regulated diseases. It is important to note that the regulations do not apply to fish caught in the wild, and that a province can, if it wishes, add more stringent requirements to the federal regulations. The Salmonidae Import Regulations are now under active review and it is anticipated that they will be expanded to include other salmonid viruses, bacteria and protozoans. In conjunction with this proposed expansion, Gillespie et al. (1974) have produced a manual of methods for the detection of the various-named pathogens. These methods are now under revision.

\section{Province of British Columbia}

In managing the freshwater fisheries resource, the Province operates a number of trout hatcheries for stocking natural waters, licenses commercial trout farms, and regulates the transfer and introduction of all species of freshwater fishes from one body of water to another. There are annual Federal-Province of British Columbia fisheries conferences to discuss matters of mutual interest, such as fish and shellfish diseases, and there is, for example, a federal-provincial committee to regulate transfers and introductions of fish into British Columbia from an ecological, genetic and health point of view.

For some years the Pacific Biological Station has accepted the task of providing a disease diagnostic and consultative service for provincial hatcheries and the agency responsible for the management of freshwater fishery resources. Soon, however, a provincially employed diagnostician will join our fish health group especially to provide service to the Province on matters of fish diseases.

\section{The Pacific Region Fish Health Program}

\section{History}

Work on parasitology of fishes, mainly salmonids, was commenced in 1952 by one of us (L.M.). Expansion of the investigations of parasitic diseases was achieved with the addition to the staff of N. P. Boyce, Dr. Z. Kabata, T. E. McDonald and D. J. Whitaker. Some earlier parasitological studies had been carried out at the Pacific Biological Station by the late Professor R. A. Wardle of the University of Manitoba and his graduate students.

In the early 1960's G. E. Hoskins, now in charge of diagnostics, and the first author began studies on microbial diseases of fishes, to be joined a few years later by Dr. T. P. T. Evelyn and J. E. Ketcheson, and most recently by G. S. Traxler. During the 1930's and early 1940's Dr. D. C. B. Duff of the University of British Columbia, working in association. with our Station, conducted some pioneering investigations, most notably into furunculosis and the possibility of oral immunization of trout against this disease.

\section{Organization and Operation}

In 1974 an expanded fish health program was implemented to meet the needs and responsibilities of the Fisheries and Marine Service in the Pacific Region. The main goals of the program are the prevention, control, and when possible, the eradication of disease: protection of stocks from the introduction of alien disease agents is considered an important aspect of prevention. 
At present we are mainly occupied with problems of infectious diseases, from viral to metazoan. Our program and concerns relate not only to acute disease resulting in mass mortalities but also to diseases which manifest themselves in sublethal ways such as retardation of growth, reduced reproductive capacity, physiological disturbances, and altered behaviour, which may or may not be predisposers to other lethal effects. Parasitic organisms which produce no visible gross effects on their hosts but render them unfit for marketing also come under study. The program has been oriented towards aetiology, epizootiology, immunology, and chemotherapy, but it will depend increasingly upon the disciplines of pathology and ecology for its further development.

There are three components of the program: health certification, diagnostics-consultation, and research. Health certification is concerned with declaring exports of cultured unprocessed salmonids from the Pacific Region "free" (in a statistical sense) of the causative agents of named diseases using a protocol specified in the regulations of the importing country or province. It is noteworthy that all interprovincial shipments of live salmonids will soon require certification. New regulations will also require that fish culture facilities rather than shipments be certified, and this certification will require examination of the facilities every 6 months.

The diagnostic-consultation component principally involves providing a service for diagnosing disease outbreaks (large or small) or diseased conditions (including presence of parasites) in cultured or wild fish, or fish products, and advising on appropriate preventive or control measures where possible. In addition, this component carries out regular disease inspection or surveillance of many fish culture facilities in order to detect incipient disease conditions. Early detection that can lead to preventive measures is the best way to reduce disease outbreaks. At present, this early detection involves the use of gross pathology, histopathology, cultural techniques for viruses and other microorganisms, direct observations for presence of parasites, as well as haematological tests such as total red blood cell counts and haematocrit. Other tests will be applied routinely as their usefulness is demonstrated. We are particularly interested in those commonly used in the clinical chemistry of mammalian blood. The diagnostic-consultation service tends to emphasize microbial and protozoan diseases because in our experience in the Pacific Region these have been the most devastating in cultured salmonid fishes. However, metazoan parasites also come under scrutiny because they can adversely affect the condition of fish.

An important function of the diagnostic service is to compile an inventory of diseases occurring among wild fishes so that management and enhancement programs will not spread disease, or fail because enzootic diseases were not taken into account.

Finally, the purpose of the research component is to provide new information that will lead to improved fish health. This information could concern the host, the aetiologic agent or the environment, or interactions of the three that affect fish health. The development of means for the prevention, control and eradication of disease in cultured fishes is given high priority. Examples of research projects are: study of some aspects of the anatomy and physiology of Pacific salmons; examination of their immune response; testing efficacy of oral and parenteral immunization of salmon against vibriosis; development of an improved culture medium for the bacterial kidney disease organism; examining the influence of the cestode Eubothrium salvelini on growth, physiological condition, and survival of wild, juvenile sockeye salmon (Oncorhynchus nerka); investigating means of treatment and control of the gill-maggott Salmincola californiensis; and examining the role of parasitic infections in disease of sea-cultured salmon. As is intended, many research projects are 
designed to be relevant to important problems encountered in the field by the diagnostician.

For maximum efficiency and economy of manpower and funds, and for the necessary close liaison among staffs responsible for each component of the Pacific Region fish health program, centralization of the various functions of the program was considered essential. The Pacific Biological Station was chosen as the site for the expanded program because it was already an established fish health research centre.

\section{Occurrence of Fish Diseases in the Pacific Region}

Since a more detailed account of the occurrence and distribution of fish diseases (including neoplasms) and disease agents in the Pacific Region, as determined mainly from our diagnostic records, will be given by G. E. Hoskins, G. R. Bell and T. P. T. Evelyn (MS in preparation), Table 1 is only a checklist. (Information on diseases and parasites in Canada may be obtained from Margolis 1970, and the report of the Canadian Committee on Fish Diseases. A check-list of the protozoan and metazoan parasites of fishes of Canada is in preparation.) Of course, the apparent absence of a disease agent may actually only mean that it has not been detected. It must also be understood that only a relatively small portion of the total fish population in this vast area has been sampled so far. Most of British Columbia and the Yukon is almost virgin territory for fish disease specialists. Not surprisingly the apparent distribution and prevalence of fish diseases coincide with the distribution and activity of fish pathobiologists!

Some diseases or disease agents deserve special comment. Bacterial kidney disease occurs among wild and cultured salmon where in the latter case the disease can be epizootic or moderately enzootic. Furunculosis appears to be widespread in cultured and wild populations of salmonids and has caused high mortalities in hatcheries. Vibriosis of salmon stocks held in sea pens was found to be caused by at least two species: $V$. anguillarum, the classical agent, and a more slow-growing, antigenically different species. A severe bacterial gill disease of cultured fish is recurrent, especially in sockeye salmon held in a particular culture facility. The aetiologic agent is an unusual gram-negative fusiform cell that fails to grow under a wide variety of cultural

TABLE 1. Threatening diseases or disease agents found in the Pacific Region ${ }^{a}$.

\begin{tabular}{|c|c|c|c|c|c|}
\hline Bacterial & Viral & Protozoan & Fungal & Metazoan & $\begin{array}{l}\text { Idiopathic } \\
\text { diseases }\end{array}$ \\
\hline $\begin{array}{l}\text { Columnaris and other } \\
\text { myxobacterioses } \\
\text { Furunculosis } \\
\text { Gill disease from an } \\
\text { unidentified } \\
\text { fusiform } \\
\text { Kidney disease } \\
\text { Mycobacteriosis } \\
\text { Vibrioses }\end{array}$ & $\begin{array}{l}\text { Infectious } \\
\text { haematopoietic } \\
\text { necrosis } \\
\text { (I.H.N.) } \\
\text { Infectious } \\
\text { pancreatic } \\
\text { necrosis } \\
\text { (I.P.N.) } \\
\text { Piscine } \\
\text { erythrocytic } \\
\text { necrosis } \\
\text { (P.E.N.)-like } \\
\text { agent }\end{array}$ & $\begin{array}{l}\text { Ceratomyxa } \\
\text { Henneguya } \\
\text { Hexamita } \\
\text { Myxidium } \\
\text { Myxobolus } \\
\text { Trichodina }\end{array}$ & $\begin{array}{l}\text { Dermocystidium } \\
\text { Saprolegnioid } \\
\text { species }\end{array}$ & $\begin{array}{l}\text { Gyrodactylus } \\
\text { Trematode } \\
\quad \text { metacercariae } \\
\text { Diphyllobothrium } \\
\text { Eubothrium } \\
\text { Philonema } \\
\text { Anisakis } \\
\text { Ergasilus } \\
\text { Caligus } \\
\text { Lepeophtheirus } \\
\text { Salmincola } \\
\text { Piscicola }\end{array}$ & $\begin{array}{l}\text { Fin rot } \\
\text { Gill disease }\end{array}$ \\
\hline
\end{tabular}

a As reported to the end of June, 1975.

$b$ Found in Alberta, close to the B. C. border.

c Presumptively diagnosed.

${ }^{d}$ Its pathogenicity is questionable but the number of cells in the brains of apparently healthy fish can be impressive. 
conditions.

I.H.N. virus has lately been found in wild sockeye and in wild and cultured chinook salmon (O. tshawytscha) on Vancouver Island, in addition to its earlier discovery at Cultus Lake, British Columbia, where it was implicated in epizootics of sockeye salmon and rainbow trout (Salmo gairdneri) (Amend et al., 1969). This virus has not yet been clearly implicated in any epizootics on the Island.

A piscine erythrocytic necrosis (P.E.N.)like agent (Laird and Bullock 1969) appears to be associated with an epizootic of cultured pink salmon ( $O$. gorbuscha) held in the ocean at Nanaimo. The filterable agent is transmissible by intraperitoneal injection to chum (O. keta) and pink salmon, but sockeye appear to be refractory (T. P. T. Evelyn and G. S. Traxler, personal communication). Investigation of this agent and disease condition is continuing.

Several coho salmon (O. kisutch) hatcheries have suffered losses apparently because of hexamitiasis and we are actively seeking an effective chemotherapeutic agent to replace the relatively ineffective epsom salts. Ceratomyxa shasta has been found in juvenile chum salmon caught at sea near Nanaimo (Margolis and Evelyn 1975) and although it has not yet been observed in a hatchery, the threat to hatchery stocks of salmon is there. A similar but probably lesser threat may be posed by the discovery of Myxidium in dense masses in the liver of an adult coho at a Vancouver Island hatchery.

Dermocystidium, now thought to be a fungus, was implicated in a massive pre-spawning mortality of wild sockeye salmon on northern Vancouver Island. Other fungal, saprolegnialike diseases appear to be ubiquitous in fresh water but because identification of the aetiologic agents and experimentation with them are difficult, the "water molds" are too often conveniently dismissed as mere secondary invaders. On this basis, one could dismiss many bacterial and protozoan diseases too.

Of the many metazoan parasites occurring in freshwater, anadromous, and marine fishes, only a few that have been associated with mortalities or have particular significance to the health of Pacific salmons will be mentioned. On several occasions in recent years Gyrodactylus on the gills or body surfaces has been responsible for mortalities among sockeye salmon in culture at our Station; control has been accomplished with formalin treatment. Eubothrium salvelini, an intestinal parasite of juvenile sockeye salmon in some British Columbia lakes, reduces growth and stamina substantially, and apparently affects survival (Smith and Margolis 1970; Smith 1973). Studies under way are aimed at assessing the impact of this cestode infection on enhanced - sockeye populations in two British Columbia lakes. The results of recent investigations at our Station involving experimental crosses of sockeye salmon suggest that one of the factors affecting survival of progeny was the intensity of infection of the female parent with Philonema oncorhynchi, a large nematode parasitic in the body cavity. Further study is required to measure the impact of this parasite on populations of its host; in some populations up to $100 \%$ of the sockeye are infected. Eye flukes, Diplostomulum metacercariae, have been found in various salmonids in some of our natural waters but epizootics, such as have been reported elsewhere, have not been reported in British Columbia. Poor survival of planted rainbow trout in a Washington State lake to the south of us has been attributed to mortalities caused by diplostomiasis (Crawford 1973).

Among the parasitic copepods, heavy infections of Salmincola californiensis have had detrimental effects on the brood stock of rainbow trout in a private fishfarm and we have frequently observed "salmon lice" (Lepeophtheirus salmonis and Caligus clemensi) during the summer months on sea-cultured salmon. The role of these caligids as disease agents in our experimental pen culture of salmon remains to be determined but serious consequences of their infections have been 
documented, particularly for $L$. salmonis on wild and cultured Atlantic salmon (White 1940; Kabata 1970; Moller 1974).

Leeches of the species Piscicola salmositica occur commonly in the gill chambers of spawning salmon in some streams, perhaps without serious consequences. Recently we found this leech species associated with mortalities of juvenile coho salmon in a seminatural rearing channel, although no cause and effect relationship was clearly established. Thomas (1969) attributed mortalities among seaward migrating chinook fry in a Washington State incubation channel to infection with this leech.

This has been a brief overview of some of the salmonid diseases encountered in British. Columbia. Much remains to be learned about them and other diseases, some undoubtedly as yet unknown, affecting salmonids and other fishes.

\section{Summary and Concluding Remarks}

A comprehensive fish health program has been initiated at the Pacific Biological Station to serve government agencies and the private sector in the Pacific Region of Canada, with priority given to salmonids as the economically most important group of fishes. Emphasis is placed on the health of cultured fish since, like other animals subjected to intensive husbandry, they appear to be more prone to disease than are wild stocks, and since cultured stocks are more readily open to prophylactic and remedial measures. The program has three components: health certification, diagnostics-consultation, and research, the staffs of which are in close liaison for maximum efficiency of operation.

Information on disease distribution is also considered important because of expanding salmonid enhancement programs and because of proposed linking of watersheds for hydroelectric development.

Not surprisingly, a number of well-known threatening disease agents are found to be widely distributed in both cultured and wild stocks in the Pacific Region. Of the protistan disease agents some are continually causing substantial problems (e.g., agents of bacterial kidney disease, furunculosis, vibriosis, hexamitiasis) while others have not been found associated with any epizootics, at least in recent years (e.g., I.H.N., I.P.N., most protozoan diseases). Certain metazoan parasite infections are also important in wild fishes and possibly in fish cultured in semi-natural conditions, but with the exception of Gyrodactylus, they have not been responsible for epizootics among fish cultured under totally artificial circumstances.

Since prevention of disease is the most effective way of improving fish health, it is hoped that new or improved diagnostic methods will enable us to detect incipient disease or disease conditions, and that improved vaccines and methods for their administration will enable the fish to withstand challenges by disease agents. Increased understanding of the ecology of disease agents will aid in devising preventive measures. Fortunately, there is a growing fund of knowledge from which we can draw, and we are grateful to our colleagues in Japan for their contributions to this fund.

\section{Acknowledgments}

We would like to thank our esteemed colleague Dr. S. Egusa for his kind invitation to present this paper.

We owe special thanks to our colleagues at the Pacific Biological Station who participated in developing the fish health program and on whose work we have liberally drawn in preparing this review. We are also grateful to other members of the Fisheries and Marine Service in the Pacific Region for useful discussions on the fish health program.

\section{References}

Amend, D. F., W. T. Yasutake, and R. W. Mead. 1969. A hematopoietic virus disease of rainbow trout and sockeye salmon: Trans. Am. Fish. Soc. 98: 796-804. 
Canadian Committee on Fish Diseases (co-chairmen G. R. Bell and L. Margolis). 1972. Considerations and recommendations for the control of fish diseases in Canada. Fish. Res. Board Can. Misc. Spec. Publ. 16: 52 p.

Crawford, B. A. 1973. An investigation of a fish kill at Waitts Lake. P. 52 in 1972 Research in Fisheries. Univ. Washington, Seattle.

Gillespie, D. C., T. P. T. Evelyn, C. Frantsi, R. M. MacKelvie, and N. Neufeld. 1974. Methods for the detection of certain pathogens of salmonid fishes. Fish. Mar. Serv. Misc. Spec. Publ. 23: 19 p.

Kabata, Z. 1970. Crustacea as enemies of fishes. In S. F. Snieszko and H. R. Axelrod [ed.] Diseases of fishes. Book 1, 171 p. T. F. H. Publications, Jersey City, New Jersey.

Laird, M., and W. L. Bullock. 1969. Marine fish haematozoa from New Brunswick and New England.

J. Fish. Res. Board Can. 26: 1075-1102.

MacCrimmon, H. R., J. E. Stewart, and J.R. Brett. 1974. Aquaculture in Canada-the practice and the promise. Fish. Res. Board Can. Bull. 188: 84 p.

Margolis, L. 1970. A bibliography of parasites and diseases of fishes of Canada: 1879-1969. Fish. Res. Board Can. Tech. Rep. 185: 38 p.

Margolis, L., and T. P. T. Evelyn. 1975. Ceratomyxa shasta (Myxosporida) disease in chum salmon (Oncorhynchus keta) in British Columbia. J. Fish. Res. Board Can. 32: 1640-1643.

Moller, D. 1974. Development of fish farming in Norway. Fish Farming International 3: 122-129.

Smith, H. D. 1973. Observations on the cestode Eubothrium salvelini in juvenile sockeye salmon (Oncorhynchus nerka) at Babine Lake, British Columbia. J. Fish. Res. Board Can. 30: 947-964.

Smith, H. D., and L. Margolis. 1970. Some effects of Eubothrium salvelini (Schrank 1790) on sockeye salmon, Oncorhynchus nerka (Walbaum), in Babine Lake, British Columbia. J. Parasitol. 56 (4, Sect. II, Part 1): 321-322.

Thomas, A. E. 1969. Mortality due to leech infestation in an incubation channel. Prog. Fish-Cult. 31: 164-165.

White, H. C. 1940. "Sea lice" (Lepeophtheirus) and death of salmon. J. Fish. Res. Board Can. 5: 172175 .

\section{Discussion}

D. Atay: What is your advice about how to prevent the introduction of disease when establishing salmonid culture in a country?

G. Bell: There are two major precautions that should be taken to prevent the introduction of disease:
1) Import eggs only (not hatched fish) from adults that have been individually tested and found free of virus (any filterpassing, replicating agent that gives a cytopathic effect on rainbow trout gonad or fathead minnow cell lines), bacteria such as those causing kidney disease, furunculosis and redmouth disease, and protozoa such as Myxosoma cerebralis and Ceratomyxa shasta. More briefly, the eggs should be taken from adults judged to be "healthy" following examination by a salmonid disease specialist.

2) Just before shipment of the eyed eggs (tests on the adults should long since have been evaluated) they should be treated with an iodophor or other chemical to disinfect the surface, rinsed with disinfected or sterilized water and shipped in disinfected containers: The purpose of this essentially aseptic procedure is to reduce the possibility of inadvertently introducing any unwanted organisms, including fish disease agents that might be in the water supply.

Despite this disinfection the use of healthy adults remains of fundamental importance because it seems possible that some disease agents, particularly viruses, might be transmitted within the egg and thus escape contact with disinfectant. I do not know of any generally effective way' to disinfect the entire egg without killing it.

These two precautions will greatly reduce but not eliminate the possibility of introduc: ing disease. No introduction or transplant is without this and other ecological hazards: If you want to be extremely cautious about the possibility of introducing disease, then the egg shipment should be placed under quarantine, using special care to prevent untreated incubation water from reaching natural water bodies. The isolation period is somewhat arbitrary but should be sufficient to cover the incubation period of common salmonid viruses, say well into the fry stage as a practical compromise.

T, Kimura: A food processing plant in 
Hokkaido, Japan imports a large number of coho salmon for smoking. In more than $10 \%$ of the salmon a milky condition has been observed after completion of the smoking process. From our studies, it was determined that the condition was related to infection with Henneguya sp. in the raw fish. May I ask you what percentage of salmon are infected with this parasite in Canada and what measures are taken for its control?

L. Margolis: As you no doubt know, Henneguya infection occurs throughout the distribution of Pacific salmons on both the Asian and North American sides of the Pacific. All species of salmons can be affected by this parasite. No surveys have been conducted specifically to determine the prevalence of Henneguya in Canadian coho salmon. Each year, however, our laboratory receives a number of cases of Henneguya infection for diagnosis. The affected salmon species usually have been coho or chum salmon and they have come from widespread localities along the coast of British Columbia. In the late 1950's the Pacific Biological Station carried out a general survey of the parasites of sockeye and pink salmon. Of about 400 British Columbia sockeye examined, only six from northern parts of the coast were infected with Henneguya; none of approximately 300 pink salmon was infected. Thus Henneguya must be regarded as uncommon in these two species of salmon. Since nothing is known about the life cycle and transmission of Henneguya, it is not possible to consider control measures.

'T. Hoshina: Mortalities of fish due to eyefluke infection apparently are rarely observed in Japan. How much damage is caused by these parasites in Canada and what species of eye-fluke is involved?

L. Margolis: To take the second part of your question first, several species of eye-flukes have been reported from wild fishes from widespread localities in Canada. In many of the reports the species involved was not identified. The most commonly identified species has been Diplostomum spathaceum; its reported hosts in Canada include a number of salmonid species. Other eyeflukes reported from Canadian fishes are Diplostomum scheuringi and D. scudderi. The extent of damage by these parasites to wild fish stocks in Canada is unknown. In the hatchery situation, Diplostomum spathaceum has been found in Atlantic salmon and brook trout (Salvelinus fontinalis) in eastern Canada. In brook trout occasional heavy infection of the eye lenses caused blindness, resulting in emaciation of the fish. The tissue-migrating cercarial stage of $D$. spathaceum produced hemorrhages and petechiae in the superficial areas of the body musculature. Although large-scale damage to fish by eye-flukes has not been reported in Canada, it is well known that blindness and mass mortalities of fish, particularly fry and fingerlings, have occurred in Europe, the U.S.S.R., and the U.S.A. Thus, these flukes must be considered potentially dangerous wherever they occur.

S. Egusa: I suppose that chemotherapeutic agents are used for the control of fish diseases in your country. What regulations do exist in Canada on the use of fish disease treatment chemicals?

G. Bell: We tend to follow U.S.A. legislation and practice. However, concern over the use of fish disease treatment chemicals (chemotherapeutic agents) is somewhat less in Canada because most of these chemicals are used on juvenile salmon before they go to sea. It is thus very likely that the flesh would be cleared of chemical long before consumption. This situation will be changing as fish farming, that is, food fish production, becomes more common. 